\title{
Chinese MBA Students' Perceptions of Business English Writing: Needs Analysis and Student Self-Reflections
}

\author{
Weiqiang Wang ${ }^{1,2} \&$ Lu Shen $^{3}$ \\ ${ }^{1}$ Center for Linguistics and Applied Linguistics, Guangdong University of Foreign Studies, Guangzhou, China \\ ${ }^{2}$ School of English for International Business, Guangdong University of Foreign Studies, Guangzhou, China \\ ${ }^{3}$ Educational Group, Guangdong University of Foreign Studies, Guangzhou, China \\ Correspondence: Lu Shen, Educational Group, Guangdong University of Foreign Studies, Guangzhou, 510420, \\ China.
}

Received: October 29, 2018 Accepted: April 1, 2019 Online Published: April 3, 2019

doi: 10.5539/elt.v12n5p20 URL: https://doi.org/10.5539/elt.v12n5p20

\begin{abstract}
Despite the steady growth in the recruitment and education of MBA students in China, there is a dearth of research on MBA students' perceptions of Business English Writing (BEW) in this context. This paper conducts a qualitative inquiry into Chinese MBA students' perceptions of BEW in English as a foreign language context in China. Forty-four MBA students of a ten-week BEW course participated in this study. An open-ended questionnaire was used near the end of the course to elicit their work-related writing needs, self-reflections on BEW abilities, and perceptions of the BEW course. A focus group was conducted with six students to provide insights into the students' work-related writing experience. The results showed that the students' work-related writing needs differed in terms of their respective job positions, with those working in foreign-funded enterprises or joint ventures having more job-related demands to write in English than those working at state-owned enterprises. Moreover, the students generally regarded their BEW abilities as moderately good or low, with distinct expectations of the BEW course raised. Pedagogic implications were drawn for improving BEW course in the Chinese context.
\end{abstract}

Keywords: Chinese MBA students, business English writing, students' perceptions, needs analysis, self-reflection

\section{Introduction}

English is a business lingua franca in the era of economic integration and globalization (Evans, 2010; Kassim \& Ali, 2010; Trinder \& Herles, 2012). Business English Writing (BEW) has been long regarded as a key communication skill especially in Asian business contexts, like Hong Kong, where the frequency of writing in English is reported to increase with the rank of those professionals (Evans, 2010). However, even in the English as a first language writing context, BEW has not been regarded as an easily acquired skill, for such reasons as the difficulty of written business communication in itself, the disjuncture between the business writing curriculum and the needs of workplace writing, and the mismatch between employers' expectations and employees' practices in workplace settings, etc. (Crosling \& Ward, 2002; Lentz, 2013; National Association of Colleges and Employers, 2010). Ever since business English existed as a field of academic inquiry, the mismatch, if any, between teaching in the Business English classroom and real business communication contexts has been a primary concern (Cowling, 2007). Louhiala-Salminen (1996), for instance, explored how the content of BEW course in formal schooling contexts might be out of pace with the widespread use of digital forms of business communication in real business contexts, particularly faxes and emails.

With China's accelerated integration into the world economy, an increasing number of Chinese MBAs are required to communicate with their foreign trading partners through English writing. There is, however, a scarcity of research on the workplace writing needs of Chinese MBA students, especially from the students' own perspectives. Students' perspectives are valuable because 'instructional planners are encouraged to develop a curriculum based on students' perceived needs in much the same way that large industrial and media agencies utilize marketing plans based on consumers' perceived needs before launching new products or programs' (Smythe \& Nikolai, 2002, p. 164). The present study aims to fill in the gap by exploring a group of Chinese 
MBA students' perceptions of BEW to better inform the design of BEW curriculum in China.

\section{Literature Review}

\subsection{The Importance of Language Needs Analysis and Student Self-Evaluation to Business English Curriculum Development}

The present study is framed within students' needs analysis with regard to their specific work-related writing demands and student self-reflections on their BEW performance, treating Business English as a manifestation of English for specific purposes (ESP). A key feature of Business English curriculum is its close match with the real-life or real working context (Sullivan \& Girginer, 2002). Language needs analysis has been an essential tool of ESP course design (Hyland, 2007), and there is no exception with Business English courses (Cowling, 2007). A more user-tailored or user-friendly curriculum can be developed by surveying or collecting students' opinions about their work-related communicative demands (Kassim \& Ali, 2010). In the present study, needs analysis refers to the process of 'identifying what learners will be required to do with the foreign language in the target situation, and how learners might best master the target language during the period of training' (West, 1994, p. $1)$.

The present study also considers students' self-reflections on their BEW abilities as an important source of information for improving the design of BEW curriculum. Students' self-reflections on their writing abilities provide course designers with a window to understand their own evaluations of present levels of writing abilities in terms of their goals of writing in workplace contexts, how well they can perform in the present working contexts, and if possible, what they plan to do to work towards those goals. Namely, student self-reflections on their own writing abilities constitute an important component of their self-regulation. Understanding student self-reflections on their present writing abilities would help course designers develop or tailor writing tasks oriented towards promoting student self-regulated writing habits and practices, which bear particular significance for MBA students, who are to spend more time in workplace settings than classroom contexts. Moreover, students' own experiences and goals are important determinants of their opinions about the teaching quality of a Business English course (Trinder \& Herles, 2012). In other words, guiding students to do self-reflections on their abilities to write in workplace settings also provides immediate feedback on the design and delivery of the course content.

\subsection{Previous Studies on BEW}

Research on BEW has mainly taken the routes of needs analysis of the learners of business English, discourse/thematic analysis of real-life business communication (e.g. Forey, 2004; Sengupta, Forey, \& Hamp-Lyons, 1999; Sullivan \& Girginer, 2002; Lockwood, 2012), and students' perceptions or experiences of specific business English courses (e.g. Trinder \& Herles, 2012). Most of the studies on business communication, including BEW, conducted linguistic analysis of the real-life business correspondences to reveal the language features of business communication. Sengupta et al. (1999) proposed a genre-approach to the development of Effective English Communication for Teaching and Research (EECTR), a program aimed at providing English language support to the academic staff at Hong Kong Polytechnic University (PolyU). Sullivan \& Girginer (2002) revealed that the communication between pilots and air-traffic controllers involved local variations of oral English, instead of merely professional airspeak. Forey (2004), assuming that teachers of BEW (BEW) may not have experience of writing in real business contexts, compared BEW teachers' and business professionals' interpretations of the text features of business correspondences. Two authentic memos written in real business contexts were chosen, with a particular focus on the participants' interpretations of the use of themes in those texts. The results showed that while the business professionals attached more importance to the ideational meanings and were mainly concerned about getting the messages across, the teachers, who treated language as the 'content' of their teaching, paid more attention to the interpersonal meanings, in particular the appropriateness of language use. The study illustrated the need for business English teachers to collaborate with business professionals when designing business English curriculum. Forey and Lockwood (2007) employed the Systemic Functional Linguistic (SFL) approach to analyze a communication breakdown in a Philippine business processing outsourcing (BPO) center and identified the linguistic choices made by the non-native English speakers (NNES) at the phonological, lexico-grammatical, clausal, and discoursal levels. Similarly, Lockwood (2012) analyzed the call-center communication breakdown in BPO sites including India and Philippines and found a mismatch between the tasks prescribed in communication syllabi and those used in real business contexts. In another study, Evans (2012), based on an analysis of more than 30 hours of interviews with English-using Chinese professionals, four case studies, and 50 email chains containing 406 messages, identified the close relationship between professionals' email exchanges and oral communication, and proposed an 
approach to the teaching of email writing by integrating speaking, listening, and writing activities.

There are fewer studies investigating the work-related needs of business communication from the user's perspective, namely, in the viewpoints of employers or (prospective) employees. Smythe and Nikolai (2002), for instance, used grounded theory to analyze the concerns statements about oral business communication from three accounting constituencies: undergraduate accounting majors, accounting graduate students, and professional accountants. They found that all the participants from the three constituencies were preoccupied with their oral communication performance, knowledge and outcomes. The undergraduate accounting majors were more concerned with personal appropriateness in oral communication, while accounting graduate students and professional accountants placed a greater stress on the accuracy of communication. Wozniak (2010) showed that for French tour mountain guides, their focus was to improve oral, rather than written, English skills. Kassim and Ali's (2010) analysis of the English communication needs of engineers working at 10 multi-national companies in Malaysia showed that oral, rather than written, communication skills were emphasized among those engineers, and that the abilities to participate in such activities as teleconferencing and do oral presentations were highly valued. Spence and Liu's (2013) English needs analysis of process integration of engineers at a semiconductor manufacturing company in Taiwan revealed that the engineers mainly used emails, teleconferences, and telephony in their routine business communication, among which emails were the most often-used means of communication. Lentz (2013) instructed students to conduct a SWOT analysis of their business writing skills and found that the students regarded their directness and detail-orientation as the strengths in writing, wordiness and straightforwardness as their weaknesses. They also saw web resources, workshops, etc. as opportunities for improving writing, while insufficient time and management support were held as threats to writing improvement. Tratnick, Urh, and Jereb (2017) administered open-ended questionnaires to 110 students at the Faculty of Organizational Science of the University of Maribor and found that the students' overall satisfaction with a business English course delivered in a face-to-face mode was higher than that delivered online. More specifically, the students reported significantly higher levels of satisfaction with course delivery, course quality, motivation, and perceived level of knowledge acquisition in the face-to-face mode. The students were also particularly satisfied with 'the range of interactive, stimulating and engaging activities' of the face-to-face mode. The study identified students' lack of motivation to learn online as a reason for their lower levels of satisfaction with the online business course. This study, however, aims to understand students' general perceptions of a business English course delivered in either a face-to-face or online mode, without examining students' opinions about the content of the course.

Most of the previous studies on BEW or Business English course in general were conducted in either such English as a foreign language (EFL) contexts as Hong Kong, Phillippine, Malaysia (e.g. Forey, 2004; Evans, 2012) or English as a native language context (e.g. Smythe and Nikolai, 2002; Lentz, 2013). There is yet a lack of research investigating Chinese students' experiences and/or perceptions of specific BEW courses. The study on the teaching of BEW in mainland China is just beginning to emerge. Zhang (2007), for instance, reviewed the traditions of business English teaching, ranging from intuition- to more research-based practices. He proposed that the focus of business English teaching should go beyond the teaching of language skills to cover the development of business expertise. Such a type of discussion, nonetheless, remains largely at the conceptual level and has not explored the mismatch, if any, that may exist between the content delivered in specific business English courses and the real-life business communicational contexts. Moreover, with only rare exceptions (e.g. Lentz, 2013), the studies on students' self-evaluation of their own abilities to write in workplace settings are few and far between. Namely, we still have very limited knowledge or understandings of how students viewed their own writing skills in specific workplace settings, though such knowledge would benefit our curriculum design and materials development regarding specific courses (Cabinda, 2013), BEW included.

\section{Context of the Study and Research Questions}

The MBA program of the present study, which is held at a university in South China famed for its foreign languages education, features an English as a medium of instruction (EMI) approach to course delivery. Namely, the teacher is supposed to teach the writing course through the use of English. The course lasted for ten weeks, twenty teaching hours, with each week being allocated two teaching hours. The BEW curriculum covers the teaching of memoranda, business letters, and business reports, with the teaching of business report writing being the curriculum's focus. All the course content was delivered using English as a medium of instruction. The present study addresses three research questions:

1) What are the students' work-related needs of BEW?

2) How do the students evaluate their own English writing abilities? 
3) What are the students' perceptions of the BEW course?

\section{Methods}

\subsection{Participants}

Forty-four students from 20 industries, ranging from telecommunications to logistics, participated in the study. The industries in which the students work cover telecommunications, energy and electricity, education, finance, and pharmacy, etc. Thirty-eight ( $86 \%$ ) of the participants came from domestic companies or institutes, while six $(14 \%)$ worked in foreign-funded enterprises. All the participants are part-time MBA students. Namely, they work on weekdays and attend the courses on weekends.

\subsection{Data Collection}

An open-ended questionnaire consisting of seven questions was administered to the students at the end of the course. The questionnaire was designed in such a way as to elicit the students' perceptions of their English writing abilities, work-related demands regarding BEW and the BEW course (see Appendix A for the open-ended questionnaire). Moreover, a focus-group centering on the research questions was conducted with six participants to gain in-depth understandings of the MBA students' perceived work-related writing needs and evaluation of the writing course. The researcher explained the purpose of the present study to all the participants and asked them to volunteer to participate in the focus group. Six students, after learning about the research purpose and considering the match between their work-related writing experience and the research, volunteered to join the focus group. The questions used in the focus group were largely similar to those used in the open-ended questionnaire, with the only exception that the questions were raised in a more interactional matter to engage the participants in active discussions of their job-related writing needs and their self-evaluations of their own writing abilities (see Appendix B for the questions used in the focus group).

\subsection{Data Analysis}

An inductive approach of the grounded theory (Corbin \& Strauss, 2015) was adopted to the analysis of the open-ended questionnaire data and the focus group results. The analysis was conducted with frequent reference to the three research questions, with a coding scheme emerging from the analysis. All the data were independently analyzed by one researcher using the coding scheme; then the data were analyzed by another researcher who has an MA degree in applied linguistics. The disagreement over the coding results was solved through discussion.

\section{Results and Discussion}

\subsection{RQ1. What Are the Students' Work-Related Needs of BEW?}

The study found that there exists a diverse range of needs among the students of different industries. The differences in those needs are largely derived from the distinctions among the industries and the job vocations of those students. Generally speaking, those students in foreign-funded or joint enterprises $(45 \%$ of all the respondents) had more work-related needs of writing in English than those in domestic $(55 \%$ of all the respondents), including both private and state-owned, enterprises. The following two excerpts, one from a student's self-report questionnaire and the other from the focus group, show the differences in the work-related demands of written English communication of a state-owned company and a foreign-funded one. For instance,

I work as a secretary at the Electricity Grid Company of Guangdong Province, and my job requirements mainly cover the drafting of internal and external documents of the company, all of which are written in Chinese only. Given the fact that my company is a state-owned enterprise in the north of Guangdong Province, there are rare occasions for me to write in English. (Student 23)

I'm a finance manager in charge of financial planning and analysis in Celestica, which is an international corporation. I have major accountabilities in my daily work as below: 1) Preparing annual plans, quarterly forecasts and bi-weekly flashes; 2) Analysis of actual $P \& L$ and forecast fluctuations to support decision making for GM and operation team; 3) Month end accounting closing; 4) Business control such as internal control, business model construction, tax issue management, etc. Since the corporation is a Singaporean enterprise, all systems and documents are coded in English. Therefore, I need to use English writing almost everywhere, like financial analysis, forecast templates, accounting documents and emails with colleagues in the company. (Focus group)

It can be seen from the first excerpt that Student 23, who works at a domestic state-owned company (the Electricity Grid Company of Guangdong Province), is mostly required to write in Chinese in her daily work. Differently, the second excerpt demonstrates that the student working in an international company (Celestica) is 
required to use English often in his routine work. Nonetheless, as noted by both respondents above, their job specifications also play an important role in determining their use of written English at work. This can be further illustrated by the following excerpt:

My present job position does not have many requirements for BEW. This is because my daily routine tasks mainly involve administration, accounting, market surveys, and sales planning of a small enterprise. I am kind of CEO of the company. But my previous job position in a trading company required me to communicate with my British colleagues through email writing. So, the differing job requirements really matter in work-related BEW. (Student, 30)

Student 30 differentiated the requirements of BEW in her previous and present job positions. Therefore, the specific positions seem to be a more accurate reference point for the identification of work-related demands of BEW. It is also interesting to note that for some respondents, even though they did not report that their job vocations had relatively high demands in terms of BEW, they felt that the improvement in English writing skills, particularly learning to compose business reports, was significant for their career development. For instance,

I am responsible for brand promotion in a hotel and convention center, which is a state-owned company. Although my job has almost no chance of using English, with the rare exceptions of translating advertisements or receiving foreign customers, I still want to improve English skills, because good English writing abilities benefit my MBA study, and more importantly, cater for the needs of my future career development. (Student 41)

Student 41 demonstrated that improving English skills, including BEW abilities, was an essential part of his plan for career development. Put another way, BEW, which may not be required at the present job position, is regarded as an important hard skill for enhancing the student's competitive edge in the job market.

In summary, the students' work-related needs, which are largely determined by the nature of the enterprises they work for, state-owned or foreign-funded ones, and the specific requirements of their job positions, have a large influence on their needs of completing on-job BEW tasks. What makes the present study different from previous analysis of students' work-related writing needs (e.g. Wozniak, 2010; Kassim \& Ali, 2010) is that the students in the present study mentioned not only their writing needs in the immediate workplace contexts but also their expected significance of improved BEW skills to career advancement. This is even the same case for those students from state-owned enterprises, where there are very limited chances of writing in English. This finding reflects the value placed by the culture on education for career development. Although there may not be immediate and urgent needs for some Chinese students to acquire and enhance their BEW skills, they are eyeing on the future promotion which may be boosted by an acquisition of writing expertise.

\subsection{RQ2. How Do the Students Evaluate Their English Writing Abilities?}

The results revealed that the students' self-evaluation of their English writing abilities was rated at three levels: 1. Fairly good; 2. Low; 3. Hard to evaluate. All the students, nonetheless, held that it is essential for them to improve their English writing skills through attending the course. Firstly, thirty-two participants $(72 \%$ of the entire group) reported that they could 'fairly' well handle their work-related English writing tasks. For instance,

I can handle it, though the way I express in writing has become more and more like speaking. It might not be appropriate, but I can let readers know what I mean. (Student 18).

I think I can meet the basic requirements of my daily work. But I still need to improve my writing skills, as the basic requirements are only from communication purpose in my daily work, and I should also prepare for higher level capabilities such as writing formal policy documents or thesis. This would be helpful to my future career. (Student 6)

I feel that although I can deal with most of the writing tasks in my daily work, my writing is still in need of improvement. This is because when it comes to English writing, my routine work is mostly related to the demonstration of my viewpoints through statistics or figures. Although I think that I have done pretty well in such duties, there is a lack of opportunities to practice using English. Moreover, I usually follow the pattern of translating Chinese directly into English when I write. As a result, there is a gap between my writing, or translations to be more exact, and the emails written by native speakers, which are more concise, more accurate, and clearer. (Focus group)

It is interesting to note that the students who felt that they could fairly well complete their work-related writing tasks had higher demands of their own English writing abilities. Such demands include, but are not confined to, the accuracy, appropriateness, concision, and clarity of English writing, etc. It is also interesting to note the differences in how articulate the students were in the self-evaluation of their writing abilities: while some students had only a fuzzy idea about being 'fairly good' at writing in English, others were more cognizant of the 
strengths and weaknesses of their work-related writing performance.

It is also worth noting that among this group of respondents, two students differentiated between their job-related and non-job-related writing duties/skills. For instance,

Since my job-related writing tasks are mostly standard emails or short reports, I can do those things pretty well. But when it comes to other tasks, like those demanding higher writing proficiency, I am not a confident writer. (Student 17)

It is obvious that the students above realized the difference between the writing performance of work-related and non-work-related tasks, which is a matter of different registers of writing.

Another twenty-one percent of them even evaluated their own English writing abilities as being 'low'. For instance,

My English writing ability is low because I have very few opportunities to write in English in my daily work. It is no exaggeration to say that my writing skills have regressed to a much lower level than in my college days. (Student 29).

I find it very difficult for me even though I am an English major. The difficulty is not the paper itself but the lack of time and energy. I find writing English paper is time consuming. As a part-time student, a father of a one-year-old child and a man with a full-time job, lacking time and energy is the biggest difficulty. (Focus group).

It is important to note that the students both attributed their 'low' writing abilities to external causes: the environmental factors. It seems that for MBA students, the job-related needs and time (and energy) availability for composing in English are key determinants of their development of English writing ability.

Another seven percent of the students said that they had 'no idea' about their present English writing levels given that there were very few opportunities of writing in English at work. For instance,

My current job duties mainly require me to communicate with foreign customers using oral English. Therefore, there are very limited or few opportunities for me to use English writing at work, and I have almost no idea about what my writing skills are like. (Student 39).

In summary, the students seemed to be divided when it came to their self-esteem about English writing abilities. Most of them felt that although they could generally handle their routine tasks of writing in English, like composing emails, drafting work-related routine reports, etc. They wanted to further improve their English writing abilities in terms of accuracy, appropriateness, and clarity of English composition. For another twenty-one percent of the students, they felt they could not 'write well' because of a lack of either time, energy, or opportunities to practice writing in daily work settings. The students seemed to have raised differing expectations of their writing skills with reference to their present levels of writing performance, which posed challenges for the development of an encompassing BEW curriculum for them.

\subsection{RQ 3. What Are the Students' Perceptions of the BEW Course?}

Three themes emerged from the analysis of the MBA students' perceptions of the MBA's BEW course: 1. Students' opinions about the usefulness of the course in improving their BEW skills; 2. The match/mismatch between the course and their work-related writing needs; 3. Students' suggestions for improving the course content and delivery.

The first theme relates to the students' perceptions regarding the effects of the writing course on their writing proficiency, particularly their general command of BEW skills. Eighty-three percent of the students held that although it was unrealistic for them to achieve significant progress in their English writing skills within such a short time, the course clarified the 'key points of BEW' to them and thus enabled them to be more poised when facing BEW tasks in the future. In particular, a respondent mentioned the effects of learning to write business reports, especially formal ones, on his performance on drafting routine auditing reports, as illustrated by the following excerpt:

Though my daily work-related writing activities are mainly auditing reports which require a rigid format, I benefit a lot from learning to write business reports in English. This is especially helpful for improving my understanding the structure and logic of the different sections of my routine auditing report, like the different functions or roles served by different sections. (Student 12).

The second theme refers to the students' mixed feelings about how well the course content corresponded to their daily work-related writing tasks. While thirty-one percent of the students felt that the course was generally well 
designed and structured, sixty-nine percent of all the respondents reported that less importance had been attached to the teaching of general business correspondence, like emails, which was an integral part of their daily routine business work. For instance,

I think that although the writing of business reports is an important type of business writing, especially with regard to the writing of our MBA graduation thesis, my daily work has more demands for writing business emails. So, I hope that more time can be spent on training us how to draft effective emails. (Student 25).

It can be seen from the excerpt that the respondents were more interested in improving the basic writing skills of regular business correspondences, especially emails, through attending the BEW course. Such phenomenon can be attributed to two factors: 1 . The prevalence of emails as a main means of business correspondence in the present business world; 2. The students' lack of confidence in their English writing proficiency, in particular the basic business writing skills.

The third theme, which is closely related to the second one, pertains to the students' suggestions for improving the content and delivery of the BEW course. Firstly, seventy-eight percent of the respondents mentioned the necessity of further enhancing their command of the basic rules of English writing. For instance,

I think that general English writing skills are more important and interesting. In addition to the ways of choosing the correct and appropriate words as well as composing well-constructed and error-free sentences, I would also prefer that the teaching hours be prolonged throughout an entire semester, namely 20 weeks. This is because it takes us a long time to consolidate what we have learnt in the class. (Focus group).

The teaching of writing course is very important and should be delivered throughout the entire MBA teaching, because it benefits both our thesis writing and daily work. (Student 3).

From the two excerpts above, it is interesting to note that despite the fact that all the students are part-time MBA students and full-time employees at different companies, some of them would prefer to have additional teaching hours to improve their English writing proficiency in the long term. Instead of expecting to make great strides in their English writing ability within a limited period of time, say 10 weeks of the present course.

Secondly, fifty-six percent of the students also hoped that more authenticity regarding the teaching content should be instilled to reflect the genuine demands of workplace settings. For instance,

It is important to teach students how to address the issues demanding writing in different business scenarios, not just formal business writing. The task requirements can be more detailed and concrete. For example, how to handle a customer complaint, how to write an invitation letter, etc. Students will be more interested in something that is closely relevant to their daily work. (Focus group).

I hope more genuine writing models will be drawn from real business contexts, especially those used in the Top 500 companies in the world. The teacher may analyze the content, structure and language features of those real-context samples, which would improve not only our writing skills but also our motivations for BEW in general. Those authentic samples would also serve as good guides for our after-class learning as well. (Student 32).

In addition to the two suggestions above, thirty-two students also advised changes in organizing and delivering the course content, in particular the time allocated to in-class writing and teacher feedback. For instance,

Although I feel that the course is generally well-organized, I still hope to have more in-class writing tasks. This is because writing cannot be improved by merely attending lectures. As a skill, it can only be enhanced by much practice and by reading and revising based on teacher feedback. Moreover, as an MBA student who works full time, it is impossible for me to practice writing after class. Therefore, it is strongly suggested that more time be spent on in-class writing tasks, which will give me a sense of urgency of task completion. (Student 16).

To sum up, the students suggested that improvements be made in the BEW course by allocating more time on in-class writing tasks and teacher feedback on student writing on the one hand and by enhancing the authenticity of the course materials on the other. Among the different types of BEW tasks, emails are the top priority of the students, which well reflected the present business working context (Spence \& Liu, 2013). Moreover, as suggested by the students, a way of establishing a stronger link between the classroom and workplace writing contexts and improving the cost-effectiveness of instruction is to use more 'authentic models of business correspondence' as course materials.

\section{Conclusion and Implications}

The present study uncovers the Chinese MBA students' perceptions of BEW, an under-explored field in both EFL and MBA education. The Chinese MBA students in the present study reported a diverse range of job-related 
needs of BEW. Those working for foreign-funded enterprises generally had more work-related needs than those working at state-owned ones. The specific job positions not only determined routine writing tasks of the students but more interestingly, their perceived general writing proficiency. For the students from foreign-funded enterprises or joint ventures, their routine writing tasks were mainly about drafting emails and other types of common business correspondences, though some of them also reported that they wrote specialized reports, like auditing reports, in daily work. For the students from state-owned enterprises, they had limited chances of writing in English. As a result, the students from state-owned enterprises have far fewer opportunities of practicing English writing skills and were also less confident about their own English writing abilities than their counterparts working at foreign-funded enterprises.

Regarding the students' self-evaluation of their BEW skills, it is important to note that though most of the students working in foreign-funded enterprises were satisfied with their current levels of writing proficiency, they wanted to improve their command of English writing skills through enhancing vocabulary use and grammar as well as emulating authentic BEW models, which are closely related to their expectations of the BEW course. The application of genre analysis to the deconstruction, reconstruction, and co-construction of BEW models would be a worthwhile endeavor, which may facilitate the students' comprehension and command of the 'steps' or 'moves' of business English correspondence. For instance, when it comes to the teaching and learning of a specific type of Business English Writing, like Application Letters, the teacher can deconstruct the model letter(s) by analyzing the moves or functions fulfilled by different parts of the letter. Then the students can be guided to reconstruct the model letter(s) by following the moves or functions identified in the deconstruction stage. As the third step, the students can work together to co-construct their own application letters by doing collaborative writing.

The study contributes to our understandings of MBA students' needs of BEW in the Chinese educational context. It has important pedagogical implications for the teaching of BEW. Given the diverse work-related needs of MBA students, who generally come from different industries, it is essential to keep a balance between the general and specific demands of their routine writing tasks. On the one hand, the curriculum of BEW needs to cover the major or common types of BEW tasks, like emails, inquiry letters, complaints, etc. On the other hand, the curriculum also needs to encompass such specialized writing tasks like work-related reports. Moreover, as suggested by the students, authentic and typical writing samples should be included to give students first-hand impressions and experiences of genuine business English correspondence. Last but not the least, considering the students' differing levels of general English proficiency, it is also important to embed the training of basic English writing skills, like word usage and sentence structures, into the curriculum.

Nonetheless, the study was conducted in a BEW course delivered at a local Chinese university. The sample size is relatively small, which diminishes its applicability to other similar contexts. Moreover, due to the limited length of the writing course, there is an insufficient coverage of the genres of writing covered.

\section{Acknowledgements}

This work was supported by the Innovative School Project in Higher Education of Guangdong, China [grant number GWTP-BS-2015-03]; the 2019 Teaching Innovation Project of Guangdong University of Foreign Studies [Investigating the Effectiveness of Formative Assessment in Business English Writing Class], Guangzhou, China.

\section{References}

Cabinda, M. (2013). The need for a needs analysis at UEM: Aspects of and attitudes towards change. Linguistics and Education, 24(4), 415-427. https://doi.org/10.1016/j.linged.2013.10.001

Corbin, J., \& Strauss, A. (2015). Basics of Qualitative Research: Techniques and Procedures for Developing Grounded Theory (4th ed.). Thousand Oaks: Sage Publications.

Cowling, J. D. (2007). Needs analysis: Planning a syllabus for a series of intensive workplace courses at a leading Japanese company. English for Specific Purposes, 26(4), 426-442. https://doi.org/10.1016/j.esp. 2006.10.003

Crosling, G., \& Ward, I. (2002). Oral communication: The workplace needs and uses of business graduate employees. English for Specific Purposes, 21(1), 41-57. https://doi.org/10.1016/S0889-4906(00)00031-4

Evans, S. (2010). Business as usual: The use of English in the professional world in Hong Kong. English for Specific Purposes, 29(3), 153-167. https://doi.org/10.1016/j.esp.2009.11.005

Forey, G. (2004). Workplace texts: Do they mean the same for teachers and business people? English for Specific Purposes, 23(4), 447-469. https://doi.org/10.1016/j.esp.2004.01.003 
Forey, G., \& Lockwood, J. (2007). "I'd love to put someone in jail for this": An initial investigation of English in the business processing outsourcing (BPO) industry. English for Specific Purposes, 26(3), 308-326. https://doi.org/10.1016/j.esp.2006.09.005

Hyland, K. (2007). English for specific purposes: Some influences and impacts. In J. Cummins, \& C. Davison (Eds.), International Handbook of English Language Teaching (pp. 391-402). Norwood, Mass: Springer. https://doi.org/10.1016/j.jeap.2007.05.001

Kassim, H., \& Ali, F. (2010). English communicative events and skills needed at the workplace: Feedback from the industry. English for Specific Purposes, 29(3), 168-182. https://doi.org/10.1016/j.esp.2009.10.002

Lentz, P. (2013). MBA Students' Workplace Writing:Implications for Business Writing Pedagogy and Workplace Practice. Business Communication Quarterly, 76(4), 474-490. https://doi.org/10.1177/108056 9913507479

Lockwood, J. (2012). Developing an English for specific purpose curriculum for Asian call centres: How theory can inform practice. English for Specific Purposes, 31(1), 14-24. https://doi.org/10.1016/j.esp.2011.05.002

Louhiala-Salminen, L. (1996). The business communication classroom vs reality: What should we teach today? English for Specific Purposes, 15(1), 37-51. doi:https://doi.org/10.1016/0889-4906(95)00024-0

National Association of Colleges and Employers. (2010). Job Outlook 2011. Retrieved from http://career.pages.tcnj.edu/files/2011/07/Job_Outlook_2011_Full_Report_PDF1.pdf

Sengupta, S., Forey, G., \& Hamp-Lyons, L. (1999). Supporting effective English communication within the context of teaching and research in a tertiary institute: developing a genre model for consciousness raising. English for Specific Purposes, 18, S7-S22. https://doi.org/10.1016/S0889-4906(99)00008-3

Smythe, M.-J., \& Nikolai, L. A. (2002). A thematic analysis of oral communication concerns with implications for curriculum design. Journal of Accounting Education, 20(3), 163-181. https://doi.org/10.1016/S07485751(02)00007-6

Spence, P., \& Liu, G.-Z. (2013). Engineering English and the high-tech industry: A case study of an English needs analysis of process integration engineers at a semiconductor manufacturing company in Taiwan. English for Specific Purposes, 32(2), 97-109. https://doi.org/10.1016/j.esp.2012.11.003

Sullivan, P., \& Girginer, H. (2002). The use of discourse analysis to enhance ESP teacher knowledge: An example using aviation English. English for Specific Purposes, 21(4), 397-404. https://doi.org/10.1016/ S0889-4906(01)00042-4

Tratnik, A., Urh, M., \& Jereb, E. (2017). Student satisfaction with an online and a face-to-face Business English course in a higher education context. Innovations in Education and Teaching International, 1-10.

West, R. (1994). Needs analysis in language teaching. Language Teaching, 27(1), 1-19. https://doi.org/10.1017/ S0261444800007527

Wozniak, S. (2010). Language needs analysis from a perspective of international professional mobility: The case of French mountain guides. English for Specific Purposes, 29(4), 243-252. https://doi.org/10.1016/j.esp. 2010.06.001

Zhang, Z. (2007). Towards an integrated approach to teaching Business English: A Chinese experience. English for Specific Purposes, 26(4), 399-410. https://doi.org/10.1016/j.esp.2006.10.006

\section{Appendix A. Questions in open-ended questionnaires}

1) Please briefly describe your job vocation.

2) Please elaborate on the needs of writing in English required by your job vocation.

3) How do you evaluate your ability to meet the needs of writing in English required by your job position?

4) What do you think about the Business English Writing course in general?

5) How well do you think the Business English Writing course meets the needs of English writing required by your job position?

6) Please feel free to make other comments or suggestions on the Business English Writing curriculum of the MBA program. 


\section{Appendix B. Questions used in the focus group}

1) Please briefly describe your job vocation, including your job position, responsibilities, etc.

2) Do you have any need to write in English in your routine work-related communication? If yes, what are those needs?

3) What do you think of your ability to meet the needs of writing in English required by your job position? Or in other words, how would you evaluate your abilities to meet the demands of writing in English in your routine work?

4) What do you think about the Business English Writing course? How well has the course fulfilled your job-related needs to write in English?

5) Please feel free to make whatever comment or suggestion on the Business English Writing curriculum of the MBA program.

\section{Copyrights}

Copyright for this article is retained by the author(s), with first publication rights granted to the journal.

This is an open-access article distributed under the terms and conditions of the Creative Commons Attribution license (http://creativecommons.org/licenses/by/4.0/). 